\title{
Prognostic value of cytophotometric analysis of DNA in lymph node aspirates from patients with non-Hodgkin's lymphoma
}

\author{
J Vučković, M Dubravčić, JM Matthews, SN Wickramasinghe, M Dominis, B Jakšić
}

\begin{abstract}
To classify cases of non-Hodgkin's $1 \mathrm{ym}$ phoma in terms of expected clinical behaviour and survival, kinetic parameters measured by cytophotometry were assessed in 62 patients between 1978 and 1987. The influence of the number of cells with increased DNA content (more than $2 \mathrm{~N}$ ) on survival was evaluated. Analyses were carried out on the small samples obtained by needle aspiration biopsy of lymph nodes before treatment, using microdensitometry and Feulgen staining. Patients whose lymphomas contained less than $6 \%$ of cells with increased DNA content had a mean survival of 81.3 months and those whose lymphomas contained $6 \%$ or more of such cells had a mean survival of 18.5 months. A significant difference in survival using the same criteria was also noticed for patients with both low grade lymphomas and those with intermediate and high grade lymphomas.

It is concluded that cytophotometric analysis of lymph node aspirates is of prognostic value in the initial assessment of non-Hodgkin's lymphoma.
\end{abstract}

Non-Hodgkin's lymphomas (NHL) are malignant lympho-proliferative disorders characterised by highly diverse clinical appearances and behaviour. ${ }^{1}$ Over the past few decades substantial efforts have been made to determine those characteristics in individual tumours which predict clinical behaviour and response to treatment. To date, the main prognostic feature has been histological classification. Using the size and the morphological appearance of the cells, as well as the pattern of growth (nodular compared with diffuse), NHL can be divided into categories of prognostic importance. ${ }^{2-4}$ Despite ongoing efforts to refine the histological criteria, pathologists are still unable to predict the behaviour of many of these tumours and the search for additional variables continues.

The kinetic behaviour of NHL has also been studied in relation to prognosis. Various techniques have been used, including mitosis counts, ${ }^{5}$ morphometry, ${ }^{6}$ tritiated thymidine $\left({ }^{3} \mathrm{HTdR}\right)$ labelling, ${ }^{7-10}$ and cytophotometry. ${ }^{11}$ Over the past decade DNA flow cytometry has been widely used to explore the kinetic features of NHL. ${ }^{12} 13$ These studies have been performed mainly on samples obtained by lymph node biopsy and not aspiration. There are only a few published papers on the cytophotometry of NHL and they have largely concerned lymph node imprints. ${ }^{11}$ The aim of this study was to try to solve the problem of assessing prognosis in NHL on the basis of cytophotometric DNA measurements in lymph node aspirates.

\section{Methods}

Ninety six patients with NHL were observed over 10 years (1978-1987). Sixty two of them, 36 men and 26 women, had suitable lymph node aspirates for DNA analysis. The age of the patients ranged from 18 to 80 years (mean 56.8 years). Mean observation time was 37.6 months. All patients were studied before treatment. Clinical staging was performed according to the Ann Arbor classification. ${ }^{14}$ Seven patients were in stage I, 14 patients were in stage IIA, and the other 41 patients were in more advanced stages of disease (IIB, III, and IV). Histological classification was carried out according to the International Working Formulation. ${ }^{4}$ Thirty patients had low grade histology. The other 32 patients with intermediate and high grade histology were considered together as a higher grade group.

Lymph node aspirates were initially smeared and stained with May-GrünwaldGiemsa stain in the standard way. Smears were destained with trichloroacetic acid and stained again by the Feulgen method. ${ }^{15}$ Cytophotometric measurements were carried out on an integrating microdensitometer (Vickers M85). Two hundred cells (including small lymphocytes) were analysed in each smear. The resulting measurements of DNA content were given in arbitrary units (AU). The quantity of DNA in the nuclei of examined cells equalling the diploid value of DNA seen in mature small lymphocytes was designated $2 \mathrm{~N}$. Deviations from the $2 \mathrm{~N}$ value were only counted as "true" deviations when they lay outside the $10 \%$ range. For example, if the value for $2 \mathrm{~N}$ (calculated as a mean value for 20 small lymphocytes) was $30 \mathrm{AU}$ then all values from 27 to $33 \mathrm{AU}$ were regarded as $2 \mathrm{~N}$. Cells with a DNA content higher than $2 \mathrm{~N}$ were considered to be in the proliferative phases of the cell cycle $\left(S, G_{2}, M\right)$ or as aneuploid. Lymphomas in which less than $6 \%$ of the total cells in the aspirate (including the small lymphocytes) had an increased DNA amount were regarded 
Fraction of cells with increased DNA content (DNA $>2 N$ ) in relation to histological subtypes of NHL

\begin{tabular}{|c|c|c|}
\hline Histolog $y^{\star}$ & $\begin{array}{l}\text { No of } \\
\text { patients }\end{array}$ & $\begin{array}{l}\text { Median for number } \\
\text { of } D N A>2 N \text { cells } \\
(\%)\end{array}$ \\
\hline \multicolumn{3}{|l|}{ Low grade } \\
\hline \multicolumn{3}{|l|}{ Lymphoplasmacytic/ } \\
\hline plasmacytoid/† & $9(14.5)$ & 3.5 \\
\hline $\begin{array}{l}\text { Follicular SCC and M (CB- } \\
\text { CC })_{+}^{\dagger}\end{array}$ & $10(16.0)$ & 5.8 \\
\hline $\begin{array}{l}\text { Other low grade } \\
\text { Intermediate and high grade }\end{array}$ & $4(6.5)$ & 1.0 \\
\hline $\begin{array}{l}\text { Intermediate and high grade } \\
\text { Diffuse } S C C \text { and } M \text { (CC, CB- } \\
\text { CC) }\end{array}$ & $5(8.1)$ & 6.5 \\
\hline Large non-cleaved (CB) & $4(6.5)$ & 19.0 \\
\hline Immunoblastic & $9(14.5)$ & 13.0 \\
\hline Large cell unclassified & $9(14.5)$ & 12.0 \\
\hline $\begin{array}{l}\text { Lymphoblastic } \\
\text { Other high grade }\end{array}$ & $\begin{array}{l}3(4.9) \\
2(3.2)\end{array}$ & 6.5 \\
\hline \multicolumn{3}{|c|}{$\begin{array}{l}\text { ^According to Internation Working Formulation; SCC-small } \\
\text { cleaved cell lymphoma; } M \text {-mixed cell lymphoma. } \\
+ \text { Included as a separate category, not as a part of lymphocytic } \\
\text { lymphoma. } \\
+ \text { CC-Centrocytic; CB-Centroblastic. }\end{array}$} \\
\hline
\end{tabular}

as low DNA (L-DNA). Other patients $(6 \%$ or more cells with increased DNA amount) were regarded as high DNA (H-DNA). Thus the L-DNA group comprised hypoproliferative cases and the H-DNA group hyperproliferative and aneuploid cases.

Statistical analysis was performed with an SAS software system. ${ }^{16}$ Life tables were calculated by the Kaplan-Meier method and compared using the Wilcoxon test. The Spearman rank correlation coefficient was also used.

\section{Results}

The fraction of cells with DNA content of more than $2 \mathrm{~N}$ varied from $0.5 \%$ to $90 \%$. Thirty two patients had less than $6 \%$ of such cells and so they belonged to the L-DNA group and 30 patients fell into the H-DNA group. The table shows the histological classifications and the median value for the number of cells with increased DNA content in each histological group. Mean actuarial survival for all patients was 55.1 months $(95 \%$ confidence interval $(\mathrm{CI})=44 \cdot 5-65 \cdot 7)$ and median survival was $\mathbf{5 0}$ months. A significant negative correlation was shown to exist between the fraction of cells with DNA content of more than $2 \mathrm{~N}$ and survival $(r=0.51$, $p=0.0001)$. Mean survival for the low grade group was 71.5 (CI 57.3-85.8, median 98) months and for the high grade group 28.1 (CI 20.8-35.5, median 22) months (fig 1). The difference in survival between the two groups was significant $(p=0.012)$. Mean survival for patients with L-DNA lymphomas was 81.3 (CI 69.5-93.1, median 98) months, and for those with H-DNA 18.5 (CI 14.7-22.3, median 19) months (fig 2). The difference was highly significant $(p=0.0001)$. In the low grade group 23 patients also belonged to the L-DNA group and their mean survival was 85 (CI 71.4-99.5, median 100) months while mean survival for the other seven patients (low grade and H-DNA) was 23.3 (CI 15.331.2 , median 20) months (fig 3 ). This

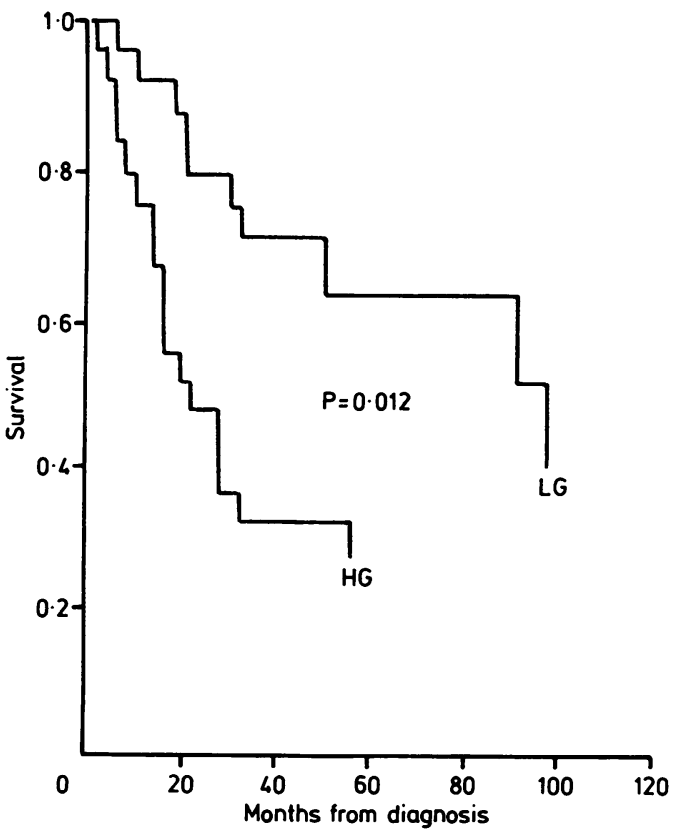

Figure 1 Survival of NHL according to the degree of malignancy; $L G=$ low grade; $H G=$ high and intermediate grade.

difference was highly significant $(p=0.0005)$. In the high grade group nine patients also belonged to L-DNA group and their mean survival was $47 \cdot 2$ (CI 33.8-60.7, median could not be calculated) months which is significantly different from the survival (mean 16.8 CI $12 \cdot 2-21 \cdot 4$, median 15 months) found in the other 23 patients of the same histological group ( $p=0.046)$ (fig 4$)$.

\section{Discussion}

The principal characteristics of our group of patients did not differ from those of other groups described elsewhere in terms of their mean age, slight male predominance, and clin-

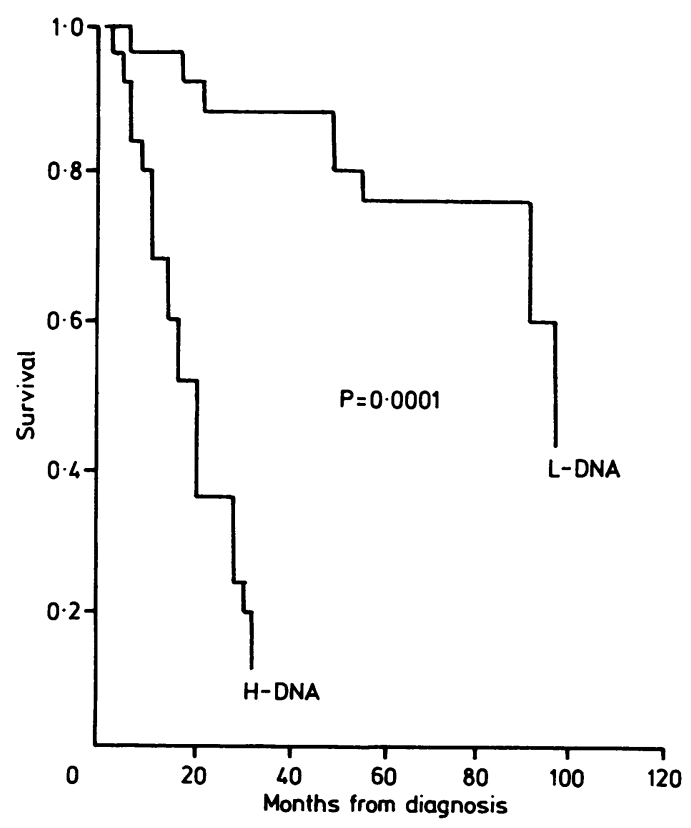

Figure 2 Survival of NHL according to DNA content. $L-D N A, N H L$ with less than $6 \%$ of cells having
increased DNA content; $H-D N A, N H L$ with $6 \%$ or
more of such cells. 
Figure 3 Survival of low grade NHL according to DNA content.

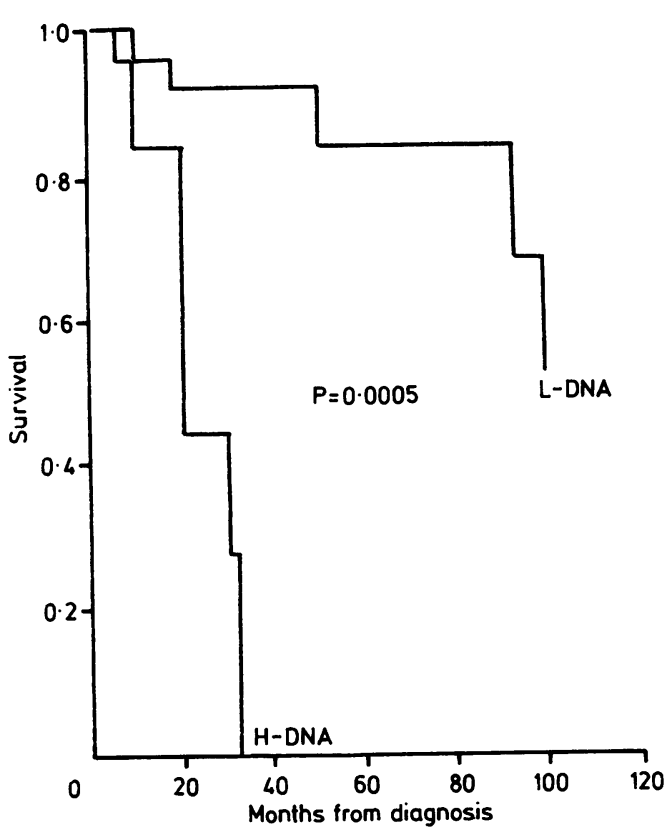

ical staging. ${ }^{31718}$ Some differences in prevalences of individual histological types might be attributable to disagreements among observers in histological interpretation and variations in the geographic distribution of NHL types. ${ }^{19} 20$

Fine needle aspiration cytology of lymph nodes has recently gained wide acceptance as an accurate method of diagnosing and classifying NHL. ${ }^{21} 22$ It is also very useful for the selection of a representative lymph node for surgical biopsy, for the diagnosis of recurrent NHL, for staging the extent of disease, for the diagnosis of cases in which tissue biopsy is not possible, and as a variable for treatment follow up. $^{23}$ Kinetic studies using $3 \mathrm{H}$-thymidine uptake $\left({ }^{3} \mathrm{HTdR}\right)$ in lymphoma cells obtained through fine needle aspiration biopsy have indicated a significant correlation between labelling index (LI) and survival. ${ }^{9} \mathrm{~A}$ high LI was associated with a poor prognosis. There

Figure 4 Survival of high grade NHL according to DNA content.

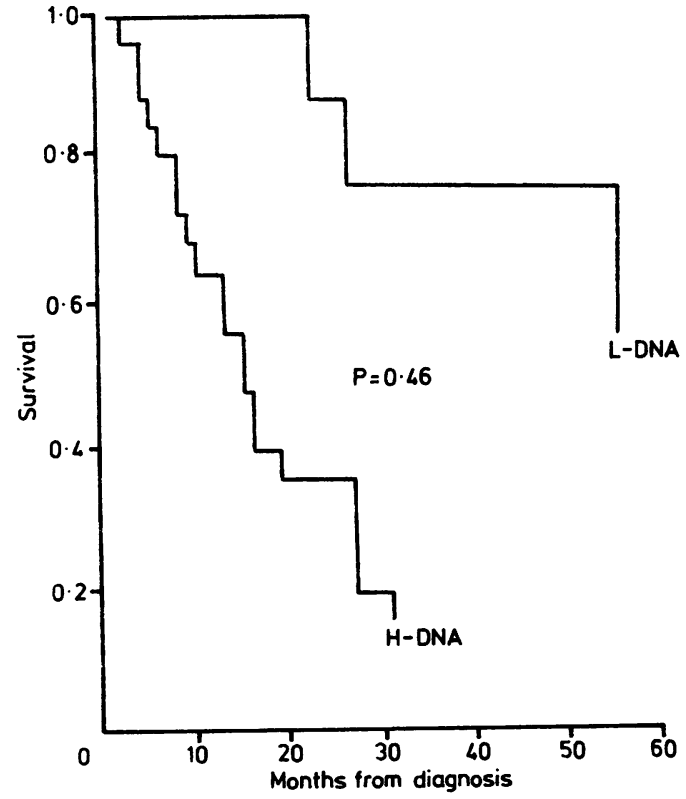

has been no such study using cytophotometry.

Kinetic techniques using histological samples have been widely used and lead to similar conclusions. It has been shown that a low mitotic index indicates longer survival in patients with low grade NHL. ${ }^{5}$ These results agree with our observation of the different behaviour pattern of low grade NHL which depends on DNA analysis. The LI is known to be a reliable variable for the prognosis of NHL.

In a series of 88 adult patients with NHL analysed by Costa et al the prognostic importance of the LI seemed to be superior to the Rappaport classification. ${ }^{9}$ Del Bino et al grouped 123 adult cases of NHL into fast proliferating and slow proliferating tumours with a discrimination point for the LI of $4.1 \% \cdot{ }^{10}$ Six year survival was $66 \%$ for slow and $18 \%$ for fast proliferating NHL. This difference in survival was highly significant $(p<0.0001)$ and very similar to the difference in survival between the L-DNA and H-DNA groups found in our study. The same authors showed a significant difference in survival dependent on the LI within the low grade lymphoma group according to the Kiel classification, and the low and intermediate grades of the Working Formulation, which was also consistent with our findings. The labelling index correlates with the $S$ phase obtained by flow cytometric analysis. ${ }^{24}$

By using flow cytometry, Lenner et al found that independent prognostic variables in NHL were clinical stage, $S$ phase fraction ("cut-off" point $4 \%$ ), and age of patient while significance was not achieved for histology and systemic signs of disease..$^{25}$ Levine et al set the discrimination point for " $S$ " between slow and fast proliferative lymphomas at $10 \%{ }^{26}$ They found that the median survival for slow proliferative NHL was over 52 months and for fast proliferative NHL 39.2 months, and concluded that there seemed to be a relation between tumour proliferative state, therapeutic response, and survival. Numerous studies deal with the kinetics of high grade lymphomas, and their conclusions are mainly consistent with ours. Wooldridge et al analysed 52 diffuse large cell and diffuse mixed NHL and set the discrimination point for "S" at $20 \%{ }^{27}$ They found a positive effect for slow proliferative states on achievement of complete remission and on survival. The predicted two year actuarial survival for slow proliferative lymphomas was $68 \%$ and for high proliferative lymphomas only $10 \%$ $(\mathrm{p}=0.01)$. Bauer et al, in a group of 50 diffuse large cell lymphomas with the same discrimination point for " $S$ ", found that high proliferative activity was the most important negative prognostic factor for survival. ${ }^{28}$ Low proliferative activity was connected with a higher rate of complete remission, but this was not significant.

It can be concluded that cytophotometric analysis of cellular DNA content, performed on material obtained by aspiration biopsy of lymph nodes, is of substantial value in assessing the prognosis of NHL. Low proliferative 
lymphomas can be determined by this method and definite prognostic characteristics can be attributed. In the H-DNA cases, although there were definite prognostic characteristics for the whole group, we could not decide with certainty whether they were really hyperproliferative or aneuploid. To resolve that problem cytophotometric analysis of a higher number of cells should be done or a flow cytometer could be used. An alternative approach is a careful mitosis count or $3 \mathrm{HTdR}$ labelling in such cases. The difference in survival of patients with NHL in each histological group, according to cytophotometric DNA analysis, indicates that this method could, at the very least, be a valuable complementary technique to histology in the initial assessment of NHL.

1 Galton DA, Catovsky D, Wiltshaw E. Clinical spectrum of lymphoproliferative diseases. Cancer 1978;42:901-10.

2 Rappaport $H$. Tumours of the hematopoietic system. In: Atlas of Tumor Pathology. Section 3, fascicle 8. Washing ton, DC: US Armed Forces Institute of Pathology, 1966

3 Jones SE, Fuks Z, Bull M, et al. Non-Hodgkin's lymphomas IV. Clinicopathologic correlation in 405 cases. Cancer 1973;31:806-23.

4 National Cancer Institute sponsored study of classification of non-Hodgkin's lymphomas. Summary and description of a working formulation for clinical usage. Cancer of a working fort

5 Evans HL, Butler JJ, Youness EL. Malignant lymphoma small lymphocytic type. A clinicopathologic study of 84 cases with suggested criteria for intermediate lymphocytic lymphoma. Cancer 1978;41:1440-55.

6 Dardic I, Sinnot NM, Hall R, Bajenko-Carr TA, Setterfield $G$. Nuclear morphology and morphometry of B-lym phocyte transformation. Am J Pathol 1983;111:35-49.

7 Silvestrini R, Piazza R, Riccardi A, Rilke F. Correlation of cell kinetic findings with morphology of non-Hodgkin's lymphomas. JNCI 1977;58:499-504.

8 Brandt $\mathrm{L}$, Olsson $\mathrm{H}$, Monti $M$. Uptake of thymidine in lymphoma cells obtained through fine-needle aspiration lymphoma cells obtained through fine-needle aspiration biopsy. Relation to prognosis in non-Hodgkin's

9 Costa A, Bonadonna G, Villa E, Valagussa P, Silvestrini R. Labelling index as a prognostic marker in non-Hodgkin's lymphomas. JNCI 1981;66:1-5.
10 Del Bino G, Silvestrini R, Costa A, Veneroni S, Giardini R. Morphological and clinical significance of cell kinetics in non-Hodgkin's lymphomas. Basic Applied Histochemistry 1986;30:197-202.

11 Sandritter $\mathbb{W}$, Grimm $H$. DNA in non-Hodgkin's lymphoma: A cytophotometric study. Beitrag Pathol 1977;160:213-30

12 Diamond LW, Braylan RC. Flow analysis of DNA content and cell size in non-Hodgkin's lymphoma. Cancer Res 1980;40:703-12.

13 Shackney SE, Skramstad KS, Cunningham RE, Dugas DJ, Lincoln TL, Lukes RJ. Dual parameter flow cytometry studies in human lymphomas. J Clin Invest 1980;66: 1281-94.

14 Carbone PP, Kaplan HS, Musshoff K, et al. Report of the committee on Hodgkin's disease staging classification. Cancer Res 1971;31:1860-1.

15 Pearse AG. Quantitative histochemistry. In: Histochemistry, Theoretical and Applied. 3rd ed. Vol. 1. London: J \& A Churchill Ltd, 1968:254-5.

16 SAS Institute Inc. SAS Users Guide: Basics, Version 5 Edition. Cary, USA:SAS Institute Inc., 1985

17 Cartwright RA, McKinney PA, Barnes N. Epidemiology of the lymphomas in the United Kingdom: Recent developments. Baillière's Clinical Haematology 1987;1:59-76.

18 Lennert K. Malignant lymphomas, other than Hodgkin's disease. New York: Springer-Verlag, 1978:106-10.

19 Ezdinli EZ, Costello W, Wasser L, et al. Eastern cooperative oncology group experience with the Rappaport classification of non-Hodgkin's lymphomas. Cancer 1979;43: 544-50.

20 Anderson RE, Ishida $\mathrm{K}$, $\mathrm{Li} \mathrm{Y}$, et al. Geographic aspects of malignant lymphoma and multiple myeloma. Am J Pathol 1970;61:85-97.

21 Orell SV, Skinner JM. The typing of non-Hodgkin's lymphomas using fine needle aspiration cytology. Pathology 1982;14:389-94.

22 Feinberg MR, Bhaskar AG, Bourne P. Differential diagnosis of malignant lymphomas by imprint cytology. Acta Cytol 1980;24:16-25.

23 van Heerde P, Go DM, Koolman Schellekens MA, Peterse JL. Cytodiagnosis of non-Hodgkin's lymphoma. Virchows Arch (Pathol Anat) 1984;403:213-33.

24 Scarffe JH, Crowther D. The pre-treatment proliferative activity of non-Hodgkin's lymphoma cells. Eur $J$ Cancer 1981;17:99-108.

25 Lenner P, Roos G, Johansson H, Lindh J, Dige U. NonHodgkin's lymphoma. Multivariate analysis of prognostic
factors including fraction of S-phase cells. Acta Oncol factors including
1987;26:179-83.

26 Levine A, Shackney S, Cunningham R, et al. Therapeutic response and survival in $B$ and $T$ cell lymphomas in relation to tumor cell aneuploidy and proliferative state. (Abstract) Proc Am Assoc Cancer Res 1981;22:520.

27 Woldridge TN, Grierson HL, Pierson JL, et al. DNA aneuploidy and low proliferative activity (PA) predict a favourable clinical outcome in diffuse large cell and mixed . Proc Am Assoc Cancer Res 1987;28:33.

28 Bauer KD, Merkl DE, Winter JN, et al. Prognostic implication of ploidy and proliferative activity in diffuse large cell lymphomas. Cancer Res 1986;46:3173-8. 